\title{
The effects of caffeic, coumaric and ferulic acids on proliferation, superoxide production, adhesion and migration of human tumor cells in vitro
}

\author{
Nouha Nasr Bouzaiene a,b,*, Soumaya Kilani Jaziri ${ }^{\mathrm{a}, \mathrm{b}}$, Hervé Kovacic ${ }^{\mathrm{c}}$, \\ Leila Chekir-Ghedira ${ }^{\mathrm{a}, \mathrm{b}}$, Kamel Ghedira ${ }^{\mathrm{a}}$, José Luis ${ }^{\mathrm{c}}$ \\ ${ }^{a}$ Unit of Bioactive and Natural Substances and Biotechnology UR12ES12, Faculty of Pharmacy, University of Monastir, Avicenne Street, Monastir 5000, \\ Tunisia \\ ${ }^{\mathrm{b}}$ Laboratory of Cellular and Molecular Biology, Faculty of Dental Medicine, University of Monastir, Avicenne Street, Monastir 5000, Tunisia \\ ' Aix Marseille Université, INSERM, UMR_S 911, Faculté de Pharmacie, 27, Boulevard Jean Moulin, 13385 Cedex 05 Marseille, France
}

\section{A R T I C L E I N F O}

\section{Article history:}

Received 9 June 2015

Received in revised form

9 September 2015

Accepted 28 September 2015

Available online 30 September 2015

Keywords:

Reactive oxygen species

Phenolic acids

Adhesion

Migration

\begin{abstract}
A B S T R A C T
Reactive oxygen species are well-known mediators of various biological responses. In this study, we examined the effect of three phenolic acids, caffeic, coumaric and ferulic acids, on superoxide anion production, adhesion and migration of human lung (A549) and colon adenocarcinoma (HT29-D4) cancer cell lines. Proliferation of both tumor cells was inhibited by phenolic acids. Caffeic, coumaric and ferulic acids also significantly inhibited superoxide production in A549 and HT29-D4 cells. Superoxide anion production decreased by $92 \%$ and $77 \%$ at the highest tested concentration $(200 \mu \mathrm{M})$ of caffeic acid in A549 and HT29-D4 cell lines respectively. Furthermore, A549 and HT29-D4 cell adhesion was reduced by $77.9 \%$ and $79.8 \%$ respectively at the higher tested concentration of ferulic acid $(200 \mu \mathrm{M})$. Migration assay performed towards A549 cell line, revealed that tested compounds reduced significantly cell migration. At the highest concentration tested $(200 \mu \mathrm{M})$, the covered surface was $7.7 \%, 9.5 \%$ and $35 \%$ for caffeic, coumaric or ferulic acids, respectively. These results demonstrate that caffeic, coumaric and ferulic acids may participate as active ingredients in anticancer agents against lung and colon cancer development, at adhesion and migration steps of tumor progression.
\end{abstract}

(c) 2015 Elsevier B.V. All rights reserved.

\section{Introduction}

Reactive oxygen species (ROS) are usually known as cytotoxic, mutagenic and linked to tumor progression. Reactive oxygen species are well-known mediators of various biological responses. Recently, new homologs of the catalytic subunit of NADPH oxidase have been discovered in non-phagocytic cells. These new homologs (Nox1-Nox5) produce low levels of superoxides compared to the phagocytic homolog Nox2/gp91phox (Sadok et al., 2008). Most anticancer drugs kill their target cells, at least in part, through the generation of elevated amounts of intracellular reactive oxygen species (Benhar et al., 2001; Jackson and Loeb, 2001; Tobiume et al., 2001). Redox homeostasis of the cell is greatly dependent on prooxidant and antioxidant enzymes. Reactive oxygen species, such as superoxide anions $\left(\mathrm{O}_{2}^{-}\right)$and hydrogen peroxide $\left(\mathrm{H}_{2} \mathrm{O}_{2}\right)$ are produced by mitochondria, peroxisome, cytochrome $\mathrm{P}-450$ and

\footnotetext{
* Corresponding author at: Unit of bioactive and natural substances and biotechnology UR12ES12, Faculty of pharmacy, University of Monastir, Avicenne Street, Monastir 5000, Tunisia. Fax: + 21673461150.

E-mail address: nouha_nasr_1987@hotmail.fr (N. Nasr Bouzaiene).
}

NADPH oxidase (D'Autreaux and Toledano, 2007) and have been shown to play a role in proliferation, apoptosis, differentiation and migration (Abid et al., 2000; Finkel, 1999). The acquisition of cell motility and the capacity to invade basement membranes and adjacent tissues plays a central role in the complex multistep process of metastasis. Cell migration results in dynamic interactions between the cell, the extracellular matrix (ECM) and the cytoskeleton. These interactions are partly mediated by integrins, a family of cell surface adhesion receptors composed by the non covalent association of $\alpha$ and $\beta$ subunits (Humphries, 2000). Integrins connect the ECM proteins outside to the actin cytoskeleton within the cell, allowing the traction required for cell migration (Geiger et al., 2001; Small et al., 1999). In addition to regulating cell adhesion, integrins relay molecular cues regarding the cellular environment that influence cell shape, survival, proliferation and gene transcription. Integrins therefore play a pivotal role during tumor progression (Hood and Cheresh, 2002; Parise et al., 2000). Currently, the search for biological antitumor agents from plants has revealed many molecules that block the growth, progression, and spread of cancer. As cancer treatments generally being preventive rather than curative (Lemjabbar-Alaoui et al., 2015), we 
looked for molecules that could intervene to prevent the spread of a tumorigenisation process already started by inhibiting or reducing the adhesion and migration of cancer cells as they are two early stages participating in the spread of a tumor. The present study shows, for the first time to our knowledge, that caffeic, coumaric and ferulic acids are potent inhibitors of superoxide anion and act by influencing the adhesion and migration of human lung (A549) and colon (HT29-D4) cancer cell lines, two preliminary steps to the tumor spread, as colorectal and lung cancers were the most common causes of cancer death in Europe for more than 50\% of all cancer incidence and mortality (Znaor et al., 2013).

\section{Materials and methods}

\subsection{Chemicals and reagents}

The phenolic acids, caffeic, ferulic and $p$-coumaric acids were purchased from Extrasynthèse (Genay, France) unless otherwise noted and were of the highest available purity. All phenolic acids were dissolved in DMSO first and then diluted with buffer (1:199, $\mathrm{v} / \mathrm{v})$.

Dulbecco's modified Eagle's medium (DMEM) and RPMI 1640 medium were purchased from Lonza (Levallois- Perret, France). Penicillin and streptomycin were purchased from GIBCO (CergyPontoise, France). Fetal bovine serum (FBS), trypsin-EDTA, L-glutamine, and sodium pyruvate were obtained from Gibco-BRL (Invitrogen, Scotland-UK). Lucigenin, methylthiazolyldiphenyl-tetrazolium bromide (MTT), poly-L-lysine, mouse laminin-1 and rat type I and VI collagens were obtained from Sigma-Aldrich (St Quentin Fallavier, France). Human fibronectin was from Millipore (St Quentin en Yvelines, France). Human vitronectin was purified according to Yatogho et al. (1988).

\subsection{Tumors cell lines and culture conditions}

Human lung A549 and human colon adenocarcinoma HT29-D4 cells were cultured in RPMI 1640 medium and DMEM, respectively. Media were supplemented with $10 \%$ fetal bovine serum (FBS), $2 \mathrm{mM}$ L-glutamine and $1 \%$ sodium pyruvate and cells were maintained at $37{ }^{\circ} \mathrm{C}$ in a humidified atmosphere with $5 \% \mathrm{CO}_{2}$.

\subsection{Cell proliferation assay}

Cell viability was assessed by MTT assay after $24 \mathrm{~h}$ incubation. 5000 cells, from exponential cultures, were incubated for $24 \mathrm{~h}$ with increasing concentrations of caffeic, coumaric and ferulic acids in a 96-well plate (Costar, Corning Inc., NY) in a final volume of $200 \mu \mathrm{l}$. Cells were exposed to $0.5 \mathrm{mg} / \mathrm{mL}$ of MTT for $3 \mathrm{~h}$ at $37{ }^{\circ} \mathrm{C}$ in the appropriate complete medium. After washing with phosphate-buffered saline (PBS), the insoluble formazan crystals were solubilized with $100 \mu \mathrm{l}$ DMSO and the absorbance was measured at $540 \mathrm{~nm}$. Each condition was performed in triplicate.

\subsection{Measurement of reactive oxygen species}

ROS generation was measured by lucigenin chemiluminescence detecting superoxide ions (Moongkarndi et al., 2004). After 30 min incubation with different compounds in 96 well plates $\left(50 \times 10^{3}\right.$ cell/well), cells were loaded with $5 \mu \mathrm{M}$ lucigenin-NADPH. Luminescence ( $490 \mathrm{~nm}$ for excitation and $538 \mathrm{~nm}$ for emission) was detected by a Fluoroscan Ascent FL fluorimeter (Labsystems, France). Results represent the integration of the signal assessed each minute for $45 \mathrm{~min}$ of measurement. All measurements were performed at $37^{\circ} \mathrm{C}$ and results are expressed as total reactive oxygen species measurements which represent the difference of reactive oxygen species production measured in untreated control

$24 \mathrm{~h}$ after seeding, cells were serum-starved for $48 \mathrm{~h}$, trypsinized and seeded in 96 well plates at a density of 50,000 cells per well in the appropriate complete media. Cells were incubated 30 min with vehicle (0.1\% DMSO) and tested molecules or the following regulators: NADPH oxidase inhibitor diphenylene iodonium (DPI) $(10 \mu \mathrm{M})$, cyclooxygenase (Cox) inhibitor indomethacin $(10 \mu \mathrm{M})$, cytochrome $\mathrm{p} 450$ inhibitor aminobenzotriazol $(1 \mathrm{mM})$, mitochondrial inhibitor rotenone $(2 \mu \mathrm{M})$ and xanthine oxidase inhibitor allopuranol $(1 \mathrm{mM})$. Results are expressed as total reactive oxygen species measurements. Results represent the percentage variation relative to untreated control.

\subsection{Cell adhesion assay}

Adhesion assays were performed as previously described (Irani et al., 1997). Briefly, flat bottom 96-well microtiter plates were coated with one of the following purified extracellular matrix (ECM) proteins: fibronectin, vitronectin, laminin 1, collagen types I and IV at $10 \mu \mathrm{g} / \mathrm{ml}$ or poly-L-lysine at $50 \mu \mathrm{g} / \mathrm{ml}$ and then were blocked with BSA. Cells were harvested and resuspended in DMEM, containing 0.2\% BSA and Hepes $10 \mathrm{mM}$ pH 7.3 (adhesion buffer) in the presence or absence of the tested molecules. After incubation for $30 \mathrm{~min}$ at room temperature, cells were added to coated wells in a volume of $50 \mu \mathrm{l}\left(10^{6} \mathrm{cells} / \mathrm{ml}\right)$ and allowed to adhere to the substrate for $1 \mathrm{~h}$ (A549 cells) or $2 \mathrm{~h}$ (HT29-D4 cells) at $37{ }^{\circ} \mathrm{C}$. Unattached cells were removed by gently washing three times with adhesion buffer. Residual attached cells were fixed by $1 \%$ glutaraldehyde, stained by $0.1 \%$ crystal violet and lysed with $1 \%$ SDS. Absorbance was then measured at $600 \mathrm{~nm}$ by a microplate reader.

\subsection{Wound healing assay}

A549 cells migration was assayed as described previously (Bazaa et al., 2009). Confluent cells in 35-mm-diameter dishes were damaged by scraping the monolayer with a sterile pipette tip ( $500 \mu \mathrm{m}$ in diameter). The cultures were washed twice with PBS to remove cellular debris and vehicle control and various concentrations of molecules were added to the respective wells. Wounds were photographed before and after $24 \mathrm{~h}$ in the presence of compounds using an Olympus inverted microscope. The migration was quantified by calculating the surface of recovery.

\subsection{Statistical analysis}

Results are expressed as means \pm S.D. from at least three independent experiments. Statistical analysis was performed using unpaired Student's test. The value of $P<0.05$ was considered statistically significant.

\section{Results}

\subsection{Phenolic acids affect cell viability}

We first evaluated the cytotoxicity of caffeic, coumaric and ferulic acids $(50-1000 \mu \mathrm{M})$ after $24 \mathrm{~h}$ of incubation on different cancer cell lines (A549 and HT29-D4) using MTT assay. As illustrated in Fig. 1, the three phenolic acids significantly inhibited the proliferation of both A549 and HT29-D4 cells in a concentrationdependent manner.

\subsection{Phenolic acids decrease superoxide production}

Dysregulated reactive oxygen species level plays a critical role 

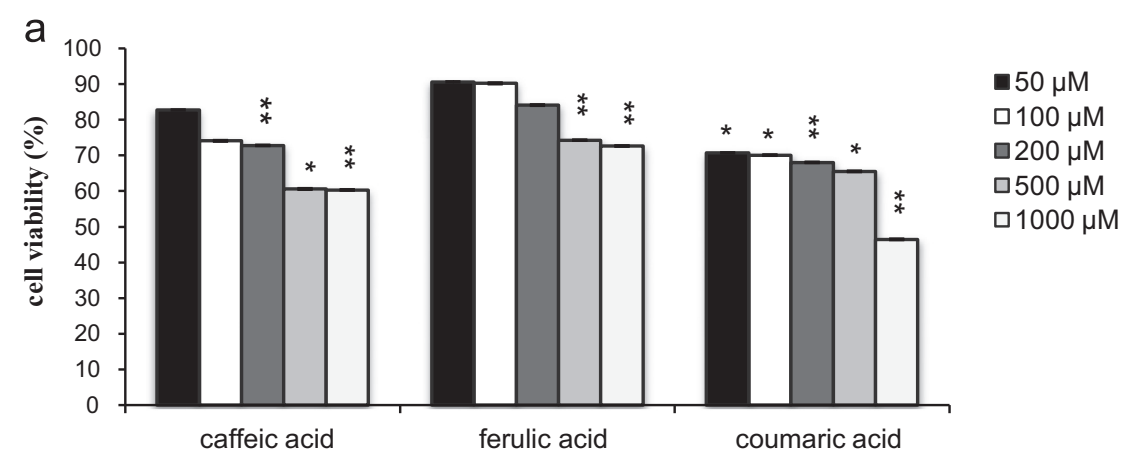

b

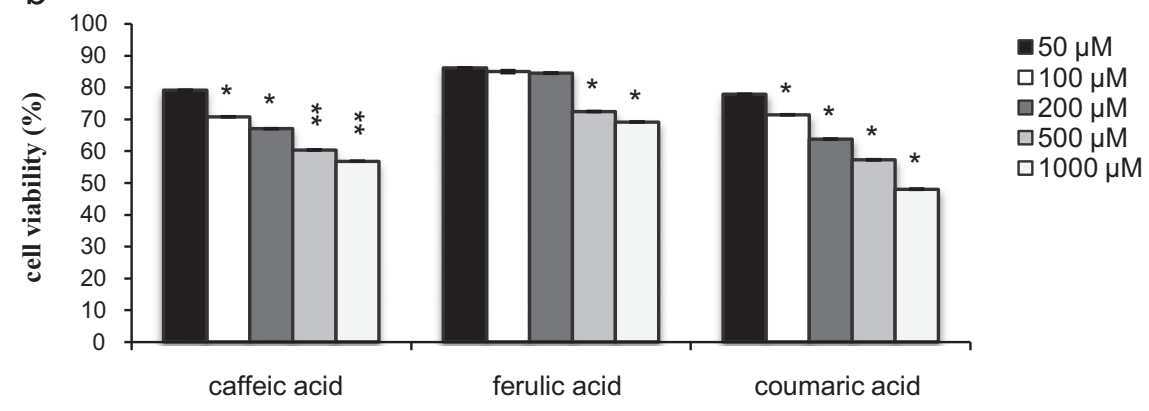

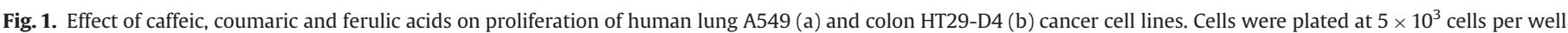

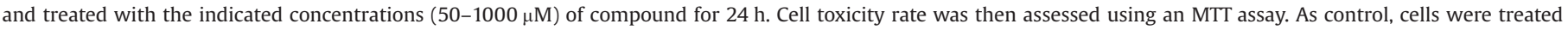
with vehicle $\left(0.1 \%\right.$ DMSO). ${ }^{*} P<0.05,{ }^{* *} P<0.01$ and ${ }^{* * *} P<0.001$ means significant difference between negative control and treated sample.

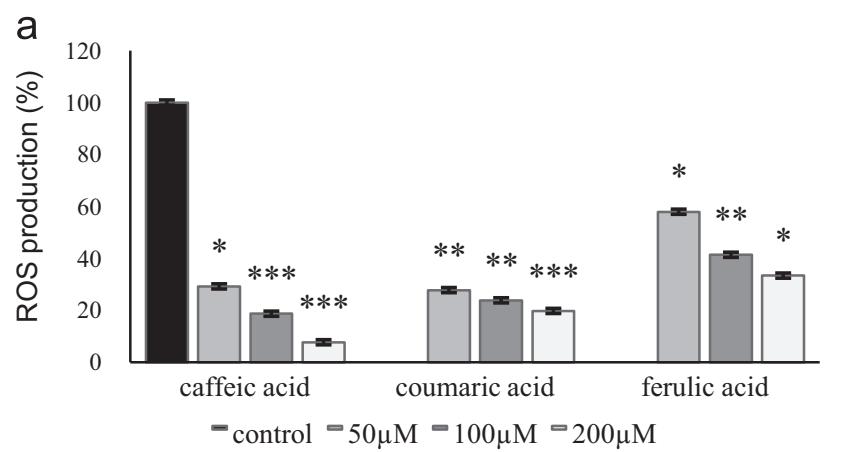

b

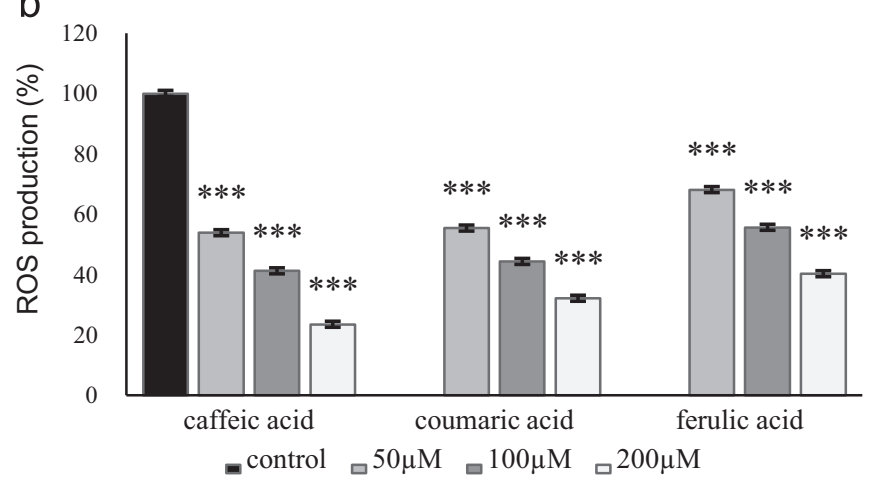

Fig. 2. Production of $\mathrm{O}_{2}^{-}$in human lung $\mathrm{A} 549$ (a) and colon HT29-D4 (b) cancer cell lines $\left(50 \times 10^{3}\right.$ cell/well) exposed to caffeic, coumaric and ferulic acids (50, 100 and $200 \mu \mathrm{M})$. Production of $\mathrm{O}_{2}^{-}$was determined by lucigenin luminescence. ${ }^{*} \mathrm{P}<0.05$, ${ }^{* *} P<0.01$ and ${ }^{* * *} P<0.001$ means significant difference between negative control and treated sample.

in cancer development. Excessive elevated ROS level confers cancer cells a susceptibility to stress-induced cell death and proliferation arrest (Park et al., 2011; Sato et al., 2014; Taboubi et al., 2007). We thus evaluated the effect of phenolic acids on ROS production by cancer cell lines. As shown in Fig. 2, pretreatment of
A549 and HT29-D4 cells with caffeic, coumaric and ferulic acids at 50,100 or $200 \mu \mathrm{M}$ during $30 \mathrm{~min}$, diminished the level of reactive oxygen species in a dose-dependent manner in comparison with the untreated cells. Superoxide anion production decreased by $92 \%$ and $77 \%$ at the highest tested concentration $(200 \mu \mathrm{M})$ of caffeic acid in A549 and HT29-D4 cell lines respectively (Fig. 2).

\subsection{Phenolic acids affect adhesion of A549 and HT29-D4 cells}

In order to investigate these phenolic acids effect on the behavior of human cell lung cancer A549 and HT29-D4 colon adenocarcinoma cells, we first performed cell adhesion assays using a large array of purified ECM proteins.

As illustrated in Figs. 3 and 4, caffeic, coumaric and ferulic acids readily impaired attachment of both A549 and HT29-D4 cells to type I collagen in a dose-dependent manner. Cell adhesion was reduced by $77.9 \%$ and $79.8 \%$ respectively at the higher tested concentration of ferulic acid $(200 \mu \mathrm{M})$. This effect was also observed with the other phenolic acids and when using type IV collagen, fibronectin and vitronectin as a matrix (Figs. 3 and 4). On the contrary, only a reduced effect was observed on poly-L-lysine for both A549 and HT29-D4.

\subsection{Phenolic acids inhibit tumor cell migration}

The migration of tumor cell lines was observed using a denudation injury model in confluent cell cultures. Scrape damaged A549 monolayers were incubated in the absence or in the presence of caffeic, coumaric or ferulic acids $(50,100$ and $200 \mu \mathrm{M})$ for $24 \mathrm{~h}$. Control cells entirely covered the wounded area after $24 \mathrm{~h}$ of incubation at $37^{\circ} \mathrm{C}$. On the contrary, treatment with phenolic acids strongly reduced wound repair (Fig. 5a). This inhibition of A549 cells migration was dose-dependent (Fig. 5a and b). At the highest concentration tested $(200 \mu \mathrm{M})$, the covered surface was $7.7 \%, 9.5 \%$ and $35 \%$ for caffeic, coumaric or ferulic acids, respectively. 

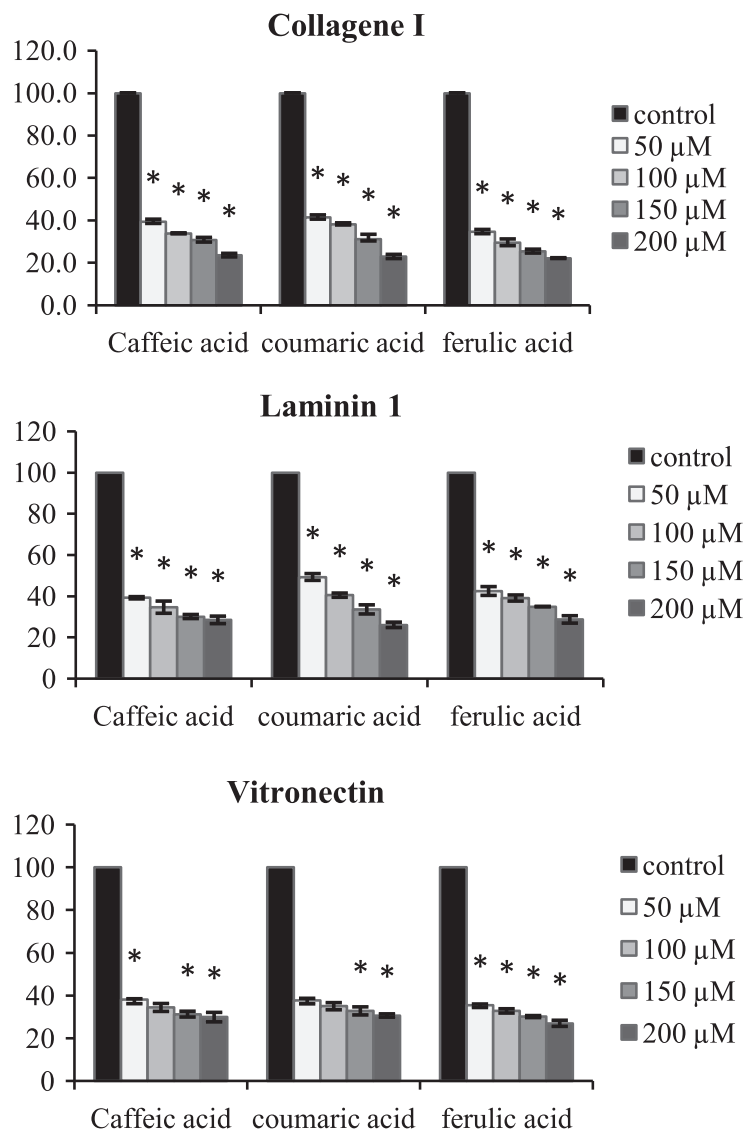
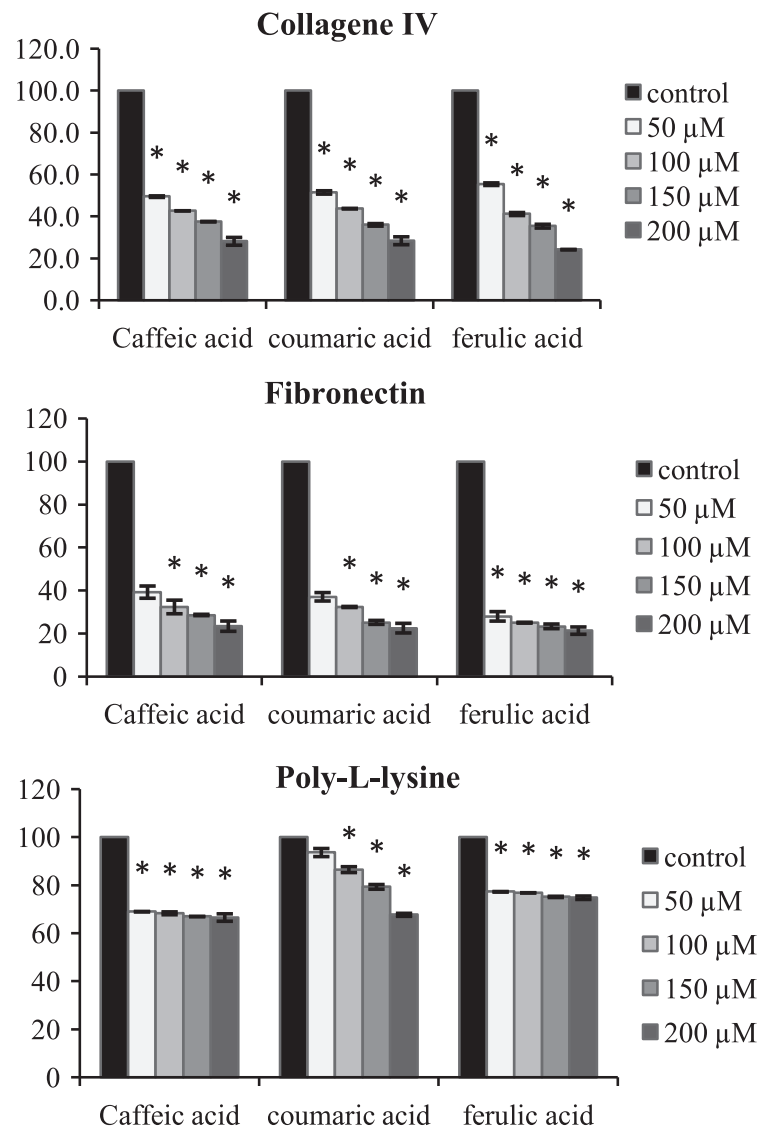

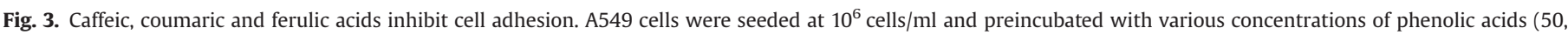

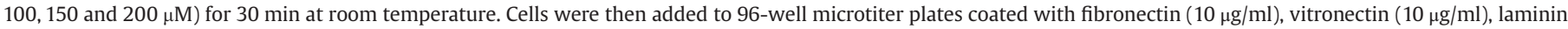

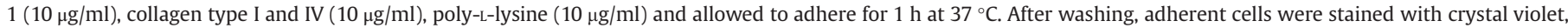

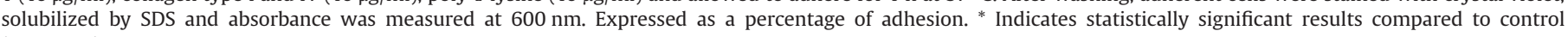
$(P<0.001)$.

\section{Discussion}

It is well known that many compounds from natural plants have chemopreventive and chemotherapeutic efficacy in human cancers (Eggler et al., 2008; Shen et al., 2014; Surh, 2003). The discovery of phytomedicinal plants as well as elucidation of their underlying mechanisms in anticancer activity is important. Caffeic, coumaric and ferulic acids, the major representative of phenolic acids, are present in many natural plants (Pan and Ho, 2008), and they have been shown to suppress tumor growth through inhibition of tumor cell proliferation and enhanced antioxidant activity (Bufalo et al., 2013).

Proliferation of human lung (A549) and colon (HT29-D4) cancer cells was significantly inhibited by the tested phenolic acids, in a dose-dependent manner, over a concentration range of 50$1000 \mu \mathrm{M}$. Maximum growth inhibition was obtained on the third day of treatment at the highest tested concentration. Such inhibitory effect has previously been observed with caffeic, coumaric and ferulic acids toward several cell lines (Berdowska et al., 2013; Bufalo et al., 2013; Damasceno et al., 2013). These inhibitory effects are likely to be mediated by the suppression of DNA synthesis, because these phenolic acids inhibited growth medium stimulated DNA synthesis in MCF-7 (Berdowska et al., 2013).

MAP kinase signaling plays a crucial role in the regulation of angiogenesis, e.g. stimulation of endothelial cell proliferation, migration (Wu et al., 2011), tube formation (Klemke et al., 1997) and expression of matrix metalloproteinase-9 (Maru et al., 1998). Bufalo et al. (2013) found that both bFGF-induced and VEGF-induced activation of ERK were blocked by these phenolic acids in endothelial cells (PBMC). The concentrations needed for inhibition of ERKs were similar to those for inhibiting endothelial cell proliferation, migration, and tube formation. Therefore, it is thus possible that the inhibition of proliferation by phenolic acids we observed in this study might be due, at least in part, to blockade of the ERK signaling pathway. However, caffeic, coumaric and ferulic acids did not affect these parameters in Raw 264.7 cells, suggesting that sensitivity of phenolic acids to ERK signaling could depend on cell type (Bufalo et al., 2013). However, we could not exclude the possibility that caffeic, coumaric and ferulic acids indirectly affect ERK signaling through an interaction with some protein kinases and/or phosphatases. Further investigations are required to determine the way of action of these compounds and to reveal the precise mechanism by which they inhibit cell proliferation.

Usually, high level of reactive oxygen species exists in tumor cells. Moreover, some tumor cells can even automatically produce reactive oxygen species, such as human colon adenocarcinoma HT29 cells and human melanoma HCT15 cells (Gum et al., 1997; Szatrowski and Nathan, 1991). In the present study, we confirmed the efficacy of these tested phenolic acids $(50-200 \mu \mathrm{M})$ in scavenging reactive oxygen species produced in A549 and HT29D4 cells, in a concentration dependent manner, as well as their ability to scavenge DPPH• and $\mathrm{O}_{2}^{-}$radicals (Gupta et al., 1999). In fact, when belonging to a concentration range, free radicals can act as cell signaling messengers by inducing signaling pathways involved in cell death without been itself directly involved in cancer cell death. A moderate increase in reactive oxygen species can promote cell proliferation and differentiation, whereas excessive amounts of ROS can cause oxidative damages. Therefore, 

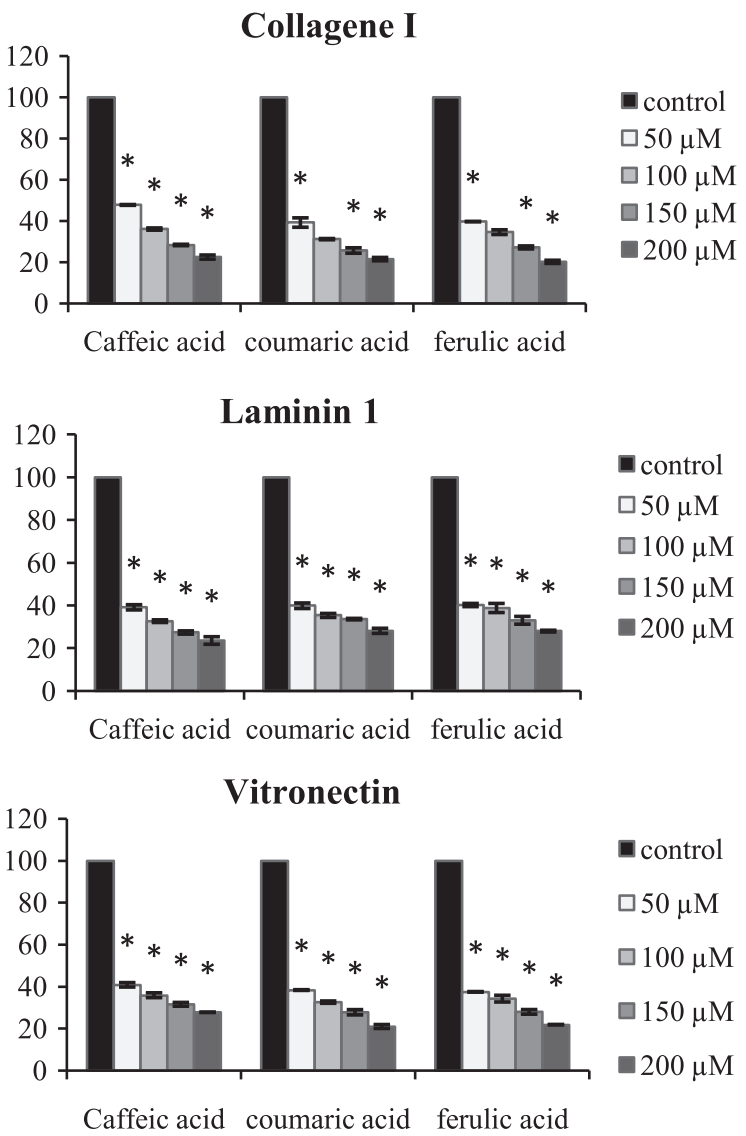

\section{Collagene IV}

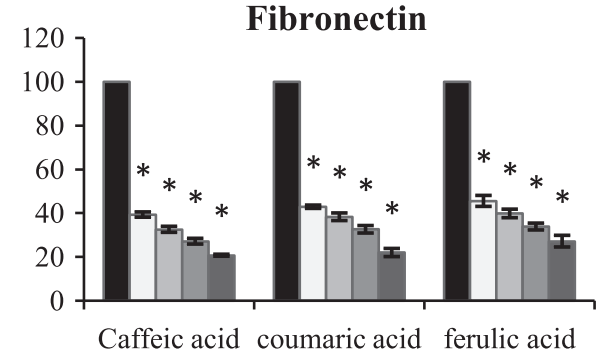

- control

$\square 50 \mu \mathrm{M}$

$\square 100 \mu \mathrm{M}$

$\square 150 \mu \mathrm{M}$

$200 \mu \mathrm{M}$

Poly-L-lysine

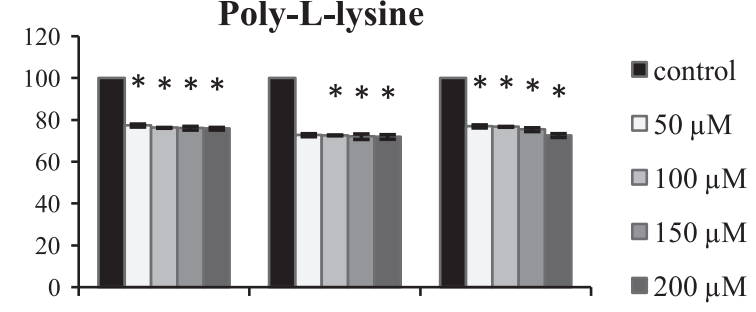

Caffeic acid coumaric acid ferulic acid

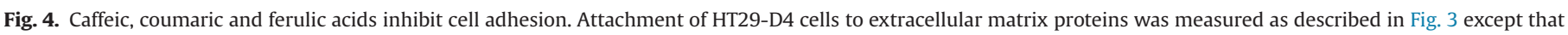
cells were allowed to adhere for $2 \mathrm{~h}$ at $37{ }^{\circ} \mathrm{C}$. Expressed as a percentage of adhesion. ${ }^{*}$ Indicates statistically significant results compared to control $(P<0.001)$.

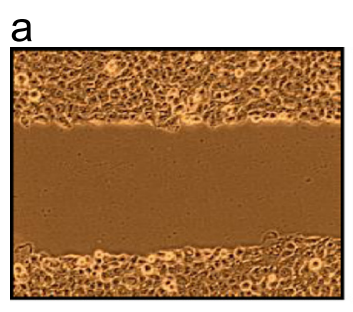

Control $\left(\mathbf{t}_{\mathbf{0}}\right)$

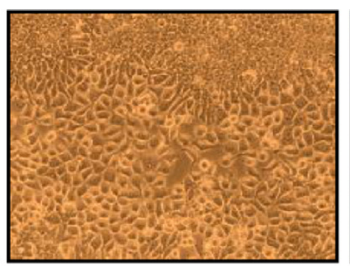

Control (24 h)

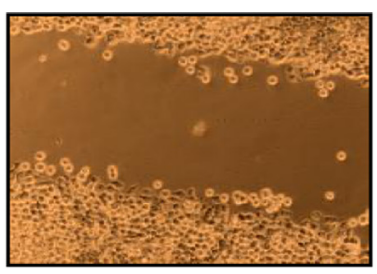

Caffeic acid (200 $\mu \mathrm{M})$

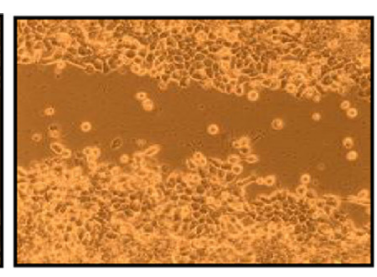

Coumaric acid $(200 \mu \mathrm{M})$

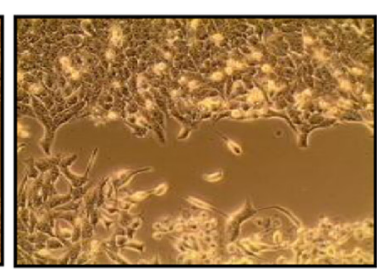

Ferulic acid (200 $\mu \mathrm{M})$

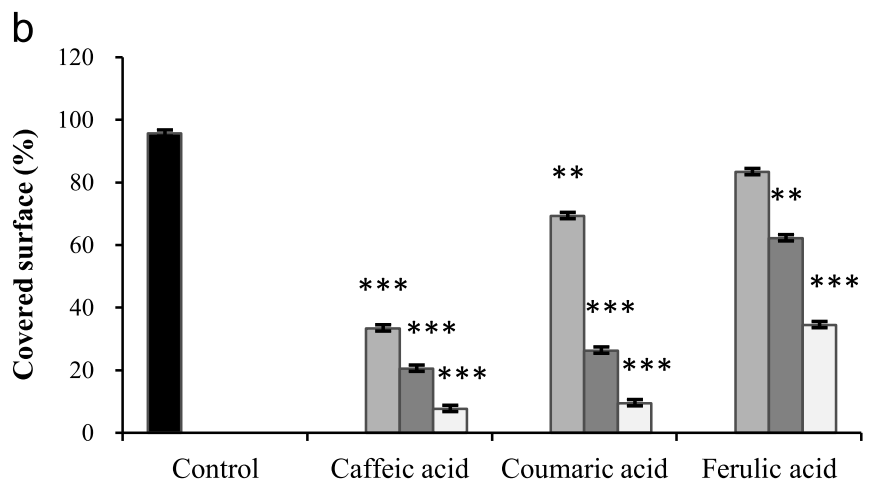

- Control
$\square 50 \mu \mathrm{M}$
$\square 100 \mu \mathrm{M}$
$\square 200 \mu \mathrm{M}$ 
contacts, mainly mediated by integrins, should undergo programmed cell death (Terpinc and Abramovič, 2010). Therefore, the characterization of new anti-integrin agents is of considerable utility for the development of therapies (Haubner et al., 2005).

In the present study we demonstrated that the phenolic acids affect adhesion of A549 and HT29-D4 cells.

Integrins are heterodimeric cell surface receptors composed of non-covalently associated transmembrane glycoproteins that connect adhesive proteins of the ECM to the cytoskeleton (Cominetti et al., 2004). $\alpha \mathrm{v}$ integrins represent an important group of adhesion molecules involved in the migration and invasion of tumor cells and in angiogenesis.

Cell migration requires the formation of new attachments at the leading edge and the release of attachments at trailing edge of the cell (Berrier and Yamada, 2007; Hood and Cheresh, 2002). Although the detailed mechanisms are not yet understood, it is clear that dynamic and reciprocal interactions between cell adhesion molecules, ECM and soluble factors are essential (Holly et al., 2000).

The inhibitory effect of caffeic, coumaric and ferulic acids on cell migration is likely due to the reduced attachment to ECM proteins observed in the presence of these phenolic acids. Similar effect was observed with glabridin against A549 cells (Tsai et al., 2011).

Our study showed that phenolic acids improve their anti-cancer activity by reducing proliferation, adhesion, migration on human lung (A549) and colon (HT29-D4) cancer cell lines. In the light of our study, caffeic, coumaric and ferulic acids appear to be very promising as potential anti-metastasic agents in vitro. Further works are necessary to explore the molecular mechanisms correlated with cellular signaling pathways. These findings reveal novel pharmacological effects for caffeic, coumaric and ferulic acids.

\section{Conclusion}

To summarize, we provide evidence that caffeic, coumaric and ferulic acids are potentially useful antioxidant agents in the treatment of human lung carcinoma and colon adenocarcinoma, suggesting that these compounds should participate to the development of therapeutic drugs for cancer diseases.

\section{Disclosure of interest}

The authors declare that they have no conflicts of interest concerning this article.

\section{Acknowledgments}

We acknowledge the "Ministère de l'enseignement supérieur, de la recherche scientifique et des technologies de l'information et de la communication, Tunisia (UR12ES12), INSERM, France (Institut National de la Santé et de la Recherche Médicale), U911 (CRO2) and ARCUS (Action en Région de Coopération Universitaire et Scientifique) (UR12ES12) for the financial support of this study.

\section{References}

Abid, M.R., Kachra, Z., Spokes, K.C., Aird, W.C., 2000. NADPH oxidase activity is required for endothelial cell proliferation and migration. FEBS Lett. 486, $252-256$.

Bazaa, A., Luis, J., Srairi-Abid, N., Kallech-Ziri, O., Kessentini-Zouari, R., Defilles, C., Lissitzky, J.C., El Ayeb, M., Marrakchi, N., 2009. MVL-PLA2, a phospholipase A2 from Macrovipera lebetina transmediterranea venom, inhibits tumor cells adhesion and migration. Matrix Biol. - J. Int. Soc. Matrix Biol. 28, 188-193.

Benhar, M., Dalyot, I., Engelberg, D., Levitzki, A., 2001. Enhanced ROS production in oncogenically transformed cells potentiates c-Jun N-terminal kinase and p38 mitogen-activated protein kinase activation and sensitization to genotoxic stress. Mol. Cell. Biol. 21, 6913-6926.

Berdowska, I., Zielinski, B., Fecka, I., Kulbacka, J., Saczko, J., Gamian, A., 2013. Cytotoxic impact of phenolics from Lamiaceae species on human breast cancer cells. Food Chem. 141, 1313-1321.

Berrier, A.L., Yamada, K.M., 2007. Cell-matrix adhesion. J. Cell. Physiol. 213, 565-573.

Bufalo, M.C., Ferreira, I., Costa, G., Francisco, V., Liberal, J., Cruz, M.T., Lopes, M.C., Batista, M.T., Sforcin, J.M., 2013. Propolis and its constituent caffeic acid suppress LPS-stimulated pro-inflammatory response by blocking NF-kappaB and MAPK activation in macrophages. J. Ethnopharmacol. 149, 84-92.

Cominetti, M.R., Terruggi, C.H., Ramos, O.H., Fox, J.W., Mariano-Oliveira, A., De Freitas, M.S., Figueiredo, C.C., Morandi, V., Selistre-de-Araujo, H.S., 2004. Alternagin-C, a disintegrin-like protein, induces vascular endothelial cell growth factor (VEGF) expression and endothelial cell proliferation in vitro. J. Biol. Chem. 279, 18247-18255.

D’Autreaux, B., Toledano, M.B., 2007. ROS as signalling molecules: mechanisms that generate specificity in ROS homeostasis. Nat. Rev. Mol Cell Biol. 8, 813-824.

Damasceno, S.S., Santos, N.A., Santos, I.M., Souza, A.L., Souza, A.G., Queiroz, N., 2013 Caffeic and ferulic acids: an investigation of the effect of antioxidants on the stability of soybean biodiesel during storage. Fuel 107, 641-646.

Eggler, A.L., Gay, K.A., Mesecar, A.D., 2008. Molecular mechanisms of natural products in chemoprevention: induction of cytoprotective enzymes by Nrf2. Mol. Nutr. Food Res. 52 (Suppl 1), S84-S94.

Finkel, T., 1999. Signal transduction by reactive oxygen species in non-phagocytic cells. J. Leukoc. Biol. 65, 337-340.

Geiger, B., Bershadsky, A., Pankov, R., Yamada, K.M., 2001. Transmembrane crosstalk between the extracellular matrix-cytoskeleton crosstalk. Nat. Rev. Mol. Cell Biol. 2, 793-805.

Gum, R., Wang, H., Lengyel, E., Juarez, J., Boyd, D., 1997. Regulation of 92 kDa type IV collagenase expression by the jun aminoterminal kinase-and the extracellular signal-regulated kinase-dependent signaling cascades. Oncogene 14, $1481-1493$.

Gupta, A., Rosenberger, S.F., Bowden, G.T., 1999. Increased ROS levels contribute to elevated transcription factor and MAP kinase activities in malignantly progressed mouse keratinocyte cell lines. Carcinogenesis 20, 2063-2073.

Haubner, R., Weber, W.A., Beer, A.J., Vabuliene, E., Reim, D., Sarbia, M., Becker, K.F. Goebel, M., Hein, R., Wester, H.J., Kessler, H., Schwaiger, M., 2005. Noninvasive visualization of the activated alphavbeta3 integrin in cancer patients by positron emission tomography and [18F]Galacto-RGD. PLoS Med. 2, e70.

Holly, S.P., Larson, M.K., Parise, L.V., 2000. Multiple roles of integrins in cell motility. Exp. Cell Res. 261, 69-74.

Hood, J.D., Cheresh, D.A., 2002. Role of integrins in cell invasion and migration. Nat Rev. Cancer 2, 91-100.

Humphries, M.J., 2000. Integrin structure. Biochem. Soc. Trans. 28, 311-339.

Irani, K., Xia, Y., Zweier, J.L., Sollott, S.J., Der, C.J., Fearon, E.R., Sundaresan, M., Finkel, T., Goldschmidt-Clermont, P.J., 1997. Mitogenic signaling mediated by oxidants in Ras-transformed fibroblasts. Science 275, 1649-1652.

Jackson, A.L., Loeb, L.A., 2001. The contribution of endogenous sources of DNA damage to the multiple mutations in cancer. Mutat. Res. 477, 7-21.

Klemke, R.L., Cai, S., Giannini, A.L., Gallagher, P.J., De Lanerolle, P., Cheresh, D.A., 1997. Regulation of cell motility by mitogen-activated protein kinase. J. Cell Biol. 137, 481-492.

Lemjabbar-Alaoui, H., Hassan, O., Yang, Y.-W., Buchanan, P., 2015. Lung cancer: biology and treatment options. Biochim. Biophys. Acta (BBA) - Rev. Cancer 1856, 189-210.

Maru, Y., Yamaguchi, S., Takahashi, T., Ueno, H., Shibuya, M., 1998. Virally activated Ras cooperates with integrin to induce tubulogenesis in sinusoidal endothelial cell lines. J. Cell. Physiol. 176, 223-234.

Moongkarndi, P., Kosem, N., Kaslungka, S., Luanratana, O., Pongpan, N., Neungton, N., 2004. Antiproliferation, antioxidation and induction of apoptosis by Garcinic mangostana (mangosteen) on SKBR3 human breast cancer cell line. J. Ethnopharmacol. 90, 161-166.

Pan, M.H., Ho, C.T., 2008. Chemopreventive effects of natural dietary compounds on cancer development. Chem. Soc. Rev. 37, 2558-2574.

Parise, L.V., Lee, J., Juliano, R.L., 2000. New aspects of integrin signaling in cancer. Semin. Cancer Biol. 10, 407-414.

Park, E.J., Choi, K.S., Kwon, T.K., 2011. Beta-Lapachone-induced reactive oxygen species (ROS) generation mediates autophagic cell death in glioma U87 MG cells. Chemico-Biol. Interact. 189, 37-44.

Sadok, A., Bourgarel-Rey, V., Gattacceca, F., Penel, C., Lehmann, M., Kovacic, H. 2008. Nox1-dependent superoxide production controls colon adenocarcinoma cell migration. Biochim. Biophys. 1783, 23-33.

Sato, A., Okada, M., Shibuya, K., Watanabe, E., Seino, S., Narita, Y., Shibui, S., Kayama, T. Kitanaka, C., 2014. Pivotal role for ROS activation of p38 MAPK in the control of differentiation and tumor-initiating capacity of glioma-initiating cells. Stem Cell Res. 12, 119-131.

Shen, S., Zhang, Y., Zhang, R., Tu, X., Gong, X., 2014. Ursolic acid induces autophagy in U87MG cells via ROS-dependent endoplasmic reticulum stress. Chemico-Biol Interact. 218, 28-41.

Small, J.V., Kaverina, I., Krylyshkina, O., Rottner, K., 1999. Cytoskeleton cross-talk during cell motility. FEBS Lett. 452, 96-99.

Surh, Y.J., 2003. Cancer chemoprevention with dietary phytochemicals. Nat. Rev. 
Cancer 3, 768-780.

Szatrowski, T.P., Nathan, C.F., 1991. Production of large amounts of hydrogen peroxide by human tumor cells. Cancer Res. 51, 794-798.

Taboubi, S., Milanini, J., Delamarre, E., Parat, F., Garrouste, F., Pommier, G., Takasaki, J., Hubaud, J.C., Kovacic, H., Lehmann, M., 2007. G alpha(q/11)-coupled P2Y2 nucleotide receptor inhibits human keratinocyte spreading and migration. FASEB J. - Off. Publ. Fed. Am. Soc. Exp. Biol. 21, 4047-4058.

Terpinc, P., Abramovič, H., 2010. A kinetic approach for evaluation of the antioxidant activity of selected phenolic acids. Food Chem. 121, 366-371.

Tobiume, K., Matsuzawa, A., Takahashi, T., Nishitoh, H., Morita, K., Takeda, K., Minowa, O., Miyazono, K., Noda, T., Ichijo, H., 2001. ASK1 is required for sustained activations of JNK/p38 MAP kinases and apoptosis. EMBO Rep. 2 222-228.

Tsai, Y.M., Yang, C.J., Hsu, Y.L., Wu, L.Y., Tsai, Y.C., Hung, J.Y., Lien, C.T., Huang, M.S. Kuo, P.L., 2011. Glabridin inhibits migration, invasion, and angiogenesis of human non-small cell lung cancer A549 cells by inhibiting the FAK/rho signaling pathway. Integr. Cancer Ther. 10, 341-349.

Wu, C.-H., Huang, H.-W., Lin, J.-A., Huang, S.-M., Yen, G.-C., 2011. The proglycation effect of caffeic acid leads to the elevation of oxidative stress and inflammation in monocytes, macrophages and vascular endothelial cells. J. Nutr. Biochem. 22, 585-594.

Yatogho, T., Izumi, M., Kashiwagi, H., Hayashi, M., 1988. Novel purification of vitronectin from human plasma by heparin affinity chromatography. Cell. Struct. Funct. 13, 281-292.

Znaor, A., van den Hurk, C., Primic-Zakelj, M., Agius, D., Coza, D., Demetriou, A., Dimitrova, N., Eser, S., Karakilinc, H., Zivkovic, S., Bray, F., Coebergh, J.W., 2013. Cancer incidence and mortality patterns in South Eastern Europe in the last decade: gaps persist compared with the rest of Europe. Eur. J. Cancer 49, 1683-1691. 